\title{
HUBUNGAN ANTARA KECERDASAN LINGUISTIK DENGAN HASIL BELAJAR ILMU PENGETAHUAN ALAM SISWA SD LABORATORIUM UNESA
}

\author{
Dewi Nurul Aini \\ (Pendidikan Guru Sekolah Dasar, Fakultas Keguruan dan Ilmu Pendidikan, \\ Universitas Adi Buana Surabaya) \\ dhewie.anggraeni@yahoo.com \\ Nurmida Catherine Sitompul \\ (Pendidikan Guru Sekolah Dasar, Fakultas Keguruan dan Ilmu Pendidikan, \\ Universitas Adi Buana Surabaya) \\ catherine sitompul@yahoo.com \\ Triman Juniarso \\ (Pendidikan Guru Sekolah Dasar, Fakultas Keguruan dan Ilmu Pendidikan, \\ Universitas Adi Buana Surabaya) \\ trimanunipa@yahoo.com
}

\begin{abstract}
This study is a correlational study, which aims to determine the relationship between linguistic students with the learning outcomes of Natural Sciences (IPA) . The population in this study are all elementary students UNESA Laboratory. Meanwhile, the sample is the entire fifth grade elementary school students UNESA Laboratory totaling 80 students.

Data were collected by using linguistic intelligence tests and documentation of learning outcomes Natural Sciences ( IPA) . Linguistic intelligence test consisting of 14 items were sourced from the internet. While documentation of science learning outcomes derived from the average value of test scores 4 times daily. Daily tests developed and implemented by the teacher concerned.

The data analysis technique used is the product moment correlation statistical techniques with calculations using SPSS version 20.

These results indicate that there is a relationship between linguistic intelligence with the Natural Sciences learning outcomes with value (rxy) of 0,578 were classified as medium category.
\end{abstract}

Keywords: linguistic intelligence, learning outcomes Natural Sciences

PENDAHULUAN

Kecerdasan merupakan salah satu anugerah besar dari Allah SWT kepada manusia dan menjadikannya sebagai salah satu kelebihan manusia dibandingkan dengan makhluk lainnya. Dengan kecerdasannya, manusia dapat terus menerus mempertahankan dan meningkatkan kualitas hidupnya yang semakin 
kompleks, melalui proses berfikir dan belajar secara terus menerus. Setiap individu tidak hanya memiliki satu kecerdasan tetapi lebih, yaitu disebut juga multiple intelligences atau kecerdasan ganda. Kecerdasan tersebut bekerja bersamaan dengan cara yang kompleks dan tidak berdiri sendiri. Akan tetapi dalam perkembangan kecerdasan gandanya, setiap siswa memiliki perbedaan kecenderungan.

Bahasa memegang peranan yang sangat

penting karena bahasa adalah alat berfikir sekaligus sebagai alat pendidikan.

Keberhasilan pembelajaran bahasa akan mempengaruhi keberhasilan pembelajaran yang lain. Bahasa memiliki peranan sentral dalam perkembangan intelektual, sosial dan emosional siswa serta merupakan kunci penentu menuju keberhasilan dalam mempelajari semua bidang ilmu. Di dalam mata pelajaran Ilmu Pengetahuan Alam dibutuhkan kemampuan dalam melakukan komunikasi ilmiah. Misalnya, ketika membicarakan tentang prinsip-prinsip ilmiah dasar yang menyangkut penemuan-penemuan tertentu. Siswa yang memiliki kecerdasan linguistik tinggi dapat menyerap dan memproses informasi dengan baik. Kecerdasan linguistik adalah kemampuan untuk menggunakan kata-kata secara efektif baik lisan maupun tulisan. Siswa yang memiliki kecerdasan linguistik akan mudah dalam mengenal atau memahami bahasa-bahasa baru, simbol-simbol, atau bahasa ilmiah yang terkandung dalam mata pelajaran Ilmu Pengetahuan Alam (IPA).

Menurut Syurfah dalam Muttaqin (2009), Pengembangan Kecerdasan Majemuk siswa hendaknya dilakukan sejak dini, minimal sejak usia Sekolah Dasar (usia 6-12 tahun) merupakan masa yang paling penting bagi anak karena halhal yang dipelajari pada usia tersebut akan menjadi pijakan bagi anak untuk perkembangan selanjutnya. Oleh karena itu perkembangan Kecerdasan Linguistik dalam Pembelajaran Ilmu Pengetahuan Alam siswa Sekolah Dasar tetap memperhatikan tingkat perkembangan kecerdasan siswa.

Siswa dengan kecerdasan linguistik tinggi cenderung memiliki daya ingat yang kuat, misalnya terhadap nama-nama orang, istilahistilah baru, simbol-simbol, maupun hal-hal yang sifatnya detail. Mereka cenderung lebih mudah belajar dengan cara mendengarkan verbalisai. Dalam penguasaan suatu bahasa baru, peserta didik ini umumnya memiliki kemampuan yang tinggi dibandingkan peserta didik lainnya (Hamzah, 2009:12).

Berdasarkan permasalahan dan latar belakang yang telah diuraikan diatas, maka penulis termotivasi untuk melakukan penelitian dengan judul "Hubungan antara Kecerdasan Linguistik dengan Hasil Belajar Ilmu 


\section{Pengetahuan Alam Siswa SD} Laboratorium UNESA". Dengan adanya penelitian ini, peneliti ingin mengetahui dan mengkaji berdasarkan penelitian yang mendalam tentang kecerdasan linguistik secara empiris di Sekolah Dasar.

Rumusan masalah dalam
penelitian ini adalah "Adakah
hubungan antara kecerdasan linguistik dengan hasil belajar Ilmu Pengetahuan Alam siswa SD Laboratorium UNESA?" Tujuan penelittian ini adalah "Untuk mengetahui hubungan antara kecerdasan linguistik dengan hasil belajar Ilmu Pengetahuan Alam siswa SD Laboratorium UNESA". Adapun manfaat teoritik dalam penelitian ini diharapkan dapat memberikan sumbangan berupa data empirik tentang kecerdasan linguistik siswa sekolah dasar dan bagaimana hubungan jenis kecerdasan ini dengan hasil belajar Ilmu Pengetahuan Alam siswa. Sedangkan manfaat praktis yaitu Temuan dari penelitian ini diharapkan memberikan informasi kepada praktisi pendidikan, khususnya guru tentang hubungan kecerdasan linguistik dengan hasil belajar Ilmu Pengetahuan Alam. Dengan demikian guru dapat memasukan aspek kecerdasan linguistik siswa dalam merancang pembelajaran Ilmu Pengetahuan Alam.

\section{METODE PENELITIAN}

Penelitian ini menggunakan metode korelasional, yaitu untuk mengetahui korelasi antara kecerdasan linguistik dengan hasil belajar Ilmu Pengetahuan Alam. Penelitian kuantitatif merupakan salah satu jenis penelitian yang spesifikasinya adalah sistematis, terencana, dan terstruktur dengan jelas sejak awal hingga pembuatan desain penelitiannya. Definisi lain menyebutkan penelitian kuantitatif adalah penelitian yang banyak menuntut penggunaan angka, mulai dari pengumpulan data, penafsiran terhadap data tersebut, serta penampilan dari hasilnya.

Adapun kerangka konseptual yang digunakan dalam penelitian ini dapat digambarkan sebagai berikut.

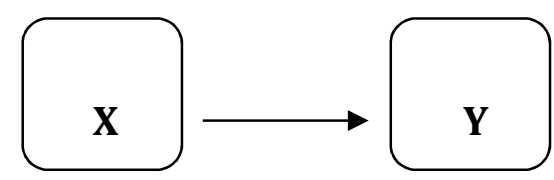

Gambar 1: Paradigma Variabel

Keterangan:

$$
\begin{aligned}
& \text { X adalah kecerdasan linguistik } \\
& \text { Y adalah hasil belajar }
\end{aligned}
$$

Tingkat kecerdasan linguistik berhubungan dengan hasil belajar siswa dalam mata pelajaran Ilmu Pengetahuan Alam.

Dalam penelitian ini yang diambil sebagai populasi adalah seluruh siswa Sekolah Dasar Laboratorium UNESA. Sedangkan sampel adalah siswa kelas V Sekolah Dasar Laboratorium UNESA dengan 
jumlah 80 siswa. Teknik pengumpulan datanya menggunakan tes kecerdasan linguistik yang digunakan untuk mengukur kecerdasan linguistik yang dimiliki oleh siswa. Serta dokumentasi yaitu nilai ulangan harian dari beberapa pokok bahasan.

Teknik analisis data digunakan adalah teknik statistik korelasional dalam perhitungan menggunakan bantuan program SPSS versi 20. Teknik statistik korelasional adalah teknik yang bertujuan untuk mencari hubungan dari dua variabel (Sugiyono, 2010:224).

Untuk menganalisis data yang telah terkumpul dari hasil penelitian ini, maka peneliti menggunakan analisis statistik dengan langkah sebagai berikut :

$$
\begin{aligned}
& \mathrm{r}_{\mathrm{xy}} \\
& \sqrt{\left(N \sum x^{2}-(x)^{2}\right)\left(N \sum y^{2}-(y)^{2}\right)}
\end{aligned}
$$

Dimana :

$\mathrm{N} \quad=$ jumlah sampel.

rxy = koefiiens korelasi antara $\mathrm{x}$, dan $\mathrm{y}$.

xy $\quad=$ product dari $\mathrm{x}$ dan $\mathrm{y}$.

$\sum x y=$ Jumlah perkalian antara variabel X dan variabel Y.

$\sum \mathrm{x} \quad=$ Jumlah nilai dari variabel $\mathrm{X}$.

$\sum \mathrm{y} \quad=$ Jumlah nilai dari variabel $\mathrm{Y}$.

$\mathrm{X}=$ skor hasil tes kecerdasan linguistik.

$\mathrm{Y}=$ nilai rata-rata hasil ulangan harian Ilmu Pengetahuan Alam

Jika nilai $\mathrm{r}_{\text {hitung }}<\mathrm{r}_{\text {tabel, }}$ maka Ho diterima dan $\mathrm{Ha}$ ditolak, maka Hipotesis berbunyi "Tidak terdapat hubungan antara kecerdasan linguistik dengan hasil belajar Ilmu Pengetahuan Alam pada siswa kelas $\mathrm{V}$ SD Laboratorium UNESA".

Untuk mengetahui interpretasi koefisien korelasi data tersebut, maka disajikan pada:

Tabel 1: Tabel Interpretasi Nilai $r$

\begin{tabular}{|c|c|}
\hline $\begin{array}{l}\text { Besarnya } \\
\text { "r" } \\
\text { Product } \\
\text { Moment } \\
\text { (rxy) }\end{array}$ & Tingkat Hubungan \\
\hline $\begin{array}{c}0,00- \\
0,20\end{array}$ & $\begin{array}{l}\text { Antara Variabel X dan } \\
\text { Variabel Y memang } \\
\text { terdapat korelasi, akan } \\
\text { tetapi korelasi itu sangat } \\
\text { lemah atau sangat } \\
\text { rendah sehingga korelasi } \\
\text { itu diabaikan (dianggap } \\
\text { tidak ada korelasi antara } \\
\text { Variabel X dan Variabel } \\
\text { Y). }\end{array}$ \\
\hline $\begin{array}{c}0,20- \\
0,40\end{array}$ & $\begin{array}{l}\text { Antara Variabel X dan } \\
\text { Variabel Y terdapat } \\
\text { korelasi yang lemah atau } \\
\text { rendah. }\end{array}$ \\
\hline $\begin{array}{c}0,40- \\
0,70\end{array}$ & $\begin{array}{l}\text { Antara Variabel X dan } \\
\text { Variabel Y terdapat } \\
\text { korelasi yang sedang } \\
\text { atau cukupan. }\end{array}$ \\
\hline $\begin{array}{c}0,70- \\
0,90\end{array}$ & $\begin{array}{l}\text { Antara Variabel X dan } \\
\text { Variabel Y terdapat } \\
\text { korelasi yang kuat atau } \\
\text { tinggi. }\end{array}$ \\
\hline
\end{tabular}




\begin{tabular}{|c|l|}
\hline $0,90-$ & \\
1,00 & $\begin{array}{l}\text { Antara Variabel X dan } \\
\text { Variabel Y terdapat } \\
\text { korelasi yang sangat kuat } \\
\text { atau sangat tinggi. }\end{array}$ \\
\hline
\end{tabular}

Sumber: Sudijono 2007 hal

\section{HASIL PENELITIAN}

Berdasarkan analisis korelasi product moment menggunakan SPSS 20, nilai $r$ hitung untuk kecerdasan linguistik dengan hasil belajar IPA adalah 0,578. Sedangkan nilai $r$ tabel dengan taraf signifikan $5 \%$ bernilai 0,217 . Dengan demikian nilai $r$ hitung $>$ nilai $\mathrm{r}$ tabel, maka $\mathrm{H}_{\mathrm{o}}$ ditolak dan $\mathrm{H}_{\mathrm{a}}$ diterima. Hipotesis berbunyi "Terdapat hubungan antara kecerdasan linguistik dengan hasil belajar Ilmu Pengetahuan Alam siswa SD Laboratorium UNESA". Arah hubungan pada korelasi tersebut dipaparkan pada grafik 1 .

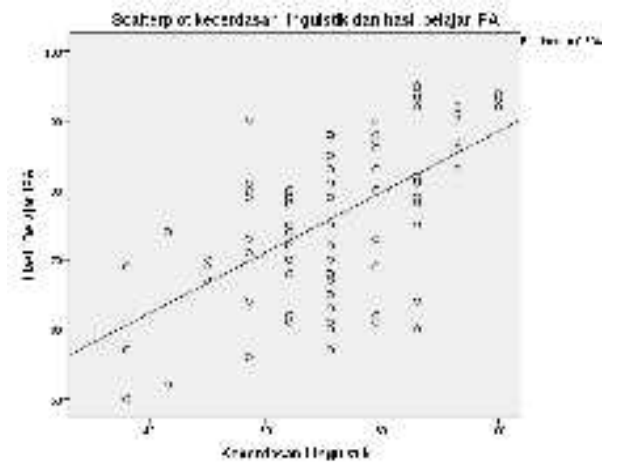

Grafik 1: Korelasi Kecerdasan

Linguistik dengan Hasil Belajar IPA

Pada grafik 4.5, garis membentang naik lurus ke arah kanan dengan tingkat kemiringan yang terjal. Grafik tersebut semakin membuktikan

ada hubungan positif yang signifikan antara kecerdasan linguistik dengan hasil belajar IPA. Sebagaimana telah dipaparkan hasil perhitungan korelasi dengan bantuan SPSS sebelumnya yang bernilai 0,578 dan dapat diterima dengan kategori sedang atau cukup.

\section{PEMBAHASAN}

Dalam

pembelajaran penggunaan suatu model Berdasarkan perhitungan korelasi product moment dengan menggunakan SPPS 20, penelitian ini menunjukkan terdapat hubungan antara kecerdasan linguistik dengan hasil belajar Ilmu Pengetahuan Alam siswa SD Laboratorium UNESA. Pada hubungan kecerdasan linguistik dengan hasil belajar Ilmu Pengetahuan Alam, rhitung bernilai 0, 578. Angka tersebut melebihi nilai $r_{\text {tabel }}$ dengan taraf signifikan $5 \%$ yang bernilai 0 , 217. Dengan demikian rhitung $>r_{\text {tabel, }}$ maka $\mathrm{H}_{\mathrm{o}}$ ditolak dan $\mathrm{H}_{\mathrm{a}}$ diterima, sehingga hasil penelitian menyatakan bahwa ada hubungan antara kecerdasan linguistik dengan hasil belajar Ilmu Pengetahuan Alam memiliki tingkat hubungan yang sedang.

Dari hasil analisis yang dilakukan, kecerdasan linguistik memiliki hubungan positif terhadap hasil belajar IPA. Pada proses pembelajaran IPA yang berlangsung di SD Laboratorium UNESA, guru cenderung menggunakan kecerdasan linguistik dalam menjelaskan menyampaikan informasi dan mengembangkan keterampilan proses 
untuk menunjang keberhasilan proses pembelajaran Ilmu Pengetahuan Alam. Proses pembelajaran tersebut sangat menguntungkan bagi siswa yang cenderung memiliki kecerdasan linguistik yang tinggi.

Hasil penelitian ini sesuai dengan hasil penelitian yang dilakukan oleh Setyowati (2009) yang menyatakan bahwa setiap orang akan dapat belajar apapun dengan mudah bila bahan itu disajikan sesuai dengan kecerdasan yang menonjol pada orang tersebut.

\section{SIMPULAN}

Berdasarkan hasil penelitian yang dilakukan pada siswa kelas V SD Laboratorium UNESA dapat disimpulkan:

"Terdapat Hubungan Antara Kecerdasan Linguistik Dengan Hasil Belajar Ilmu Pengetahuan Alam Siswa SD Laboratorium UNESA". Hubungan tersebut memiliki tingkat korelasi yang sedang dengan koefisien korelasi 0,578 .

\section{SARAN}

Berdasarkan kesimpulan di atas, maka beberapa saran yang mungkin dapat berguna yaitu sebagai berikut:

1) Dalam melaksanakan kegiatan belajar mengajar, khususnya pada mata pelajaran Ilmu Pengetahuan Alam sebaiknya guru tetap memperhatikan kecerdasan linguistik yang dimiliki pada setiap siswa. Hal ini disebabkan karena setiap siswa memiliki tingkat kecerdasan yang berbeda dengan siswa lainnya.

2) Dalam merancang perangkat pembelajaran, diharapkan guru dapat memperhatikan karakteristik peserta didik pada usia Sekolah Dasar.

3) Dalam mengembangkan potensi dalam diri siswa, guru diharapkan dapat membimbing dan mengarahkan sesuai tingkat kecerdasan yang tinggi pada diri siswa.

\section{DAFTAR PUSTAKA}

Arikunto, Suharsimi. 2010. Prosedur Penelitian Suatu Pendekatan Praktis. Jakarta: Indeks.

Armstrong, Thomas. 2013. Kecerdsan Multipel di dalam Kelas. Jakarta: Indeks.

Fakultas Keguruan dan Ilmu Kependidikan. 2013. Pedoman Penulisan Skripsi dan Artikel Ilmiah. Surabaya: UNIPA.

Gintings, Abdorrakhman. 2007. Esensi Praktis Belajar dan Pembelajaran. Bandung: Humaniora.

Hartono, CRJ. 2012. Hubungan Antara Kecepatan Lari Zig-zag Dengan Prestasi Menembak Bola Kering Permentit Dalam Permainan Bola Basket Siswa Putra Kelas IX di SMK Antartika 2 Sidoarjo. Skripsi: 
Universitas PGRI Adi Buana Surabaya.

Muttaqin, Imamul. 2009. Analisis Multiple Intelligences Dalam Pendidikan Agama Islam di SD Islam Sabilillah Sidoarjo Jawa Timur. Skripsi: Universitas Islam Negeri Sunan Kalijaga.

Rumapea, Rinaldi. 2012. Pengaruh Strategi Pembelajaran Berbasis Multiple Intelligences Terhadap Hasil Belajar Siswa Pada Materi Pokok Getaran dan Gelombang di Kelas VIII Semester II SMP Negeri I
Lumbanjulu T.P 2011/2012. UNIMED.

Swasti, dkk. 2013. Pengaruh Model Pembelajaran Kontekstual Dan Kecerdasan Linguistik Terhadap Keterampilan Menulis Dalam Bhasa Inggris Bagi Siswa Kelas $X$ di SMK Negeri 1 Abang. Vol. 3

Uno, Hamzah B dkk. 2009. Mengelola Kecerdasan Dalam Pembelajaran sebuah Konsep Pembelajaran Berbasis Kecerdasan. Jakarta: Bumi Aksara. 